\title{
The Diego Factor among Assiatic Indians, Apaches and West African Negroes; Blood Types of Asiatic Indians and Apaches ${ }^{1}$
}

\author{
HENRY GERSHOWITZ \\ Department of Human Genetics, University of Michigan
}

The apparent restriction of the Diego blood factor to the Mongoloid peoples (Leyrisse and Arends, '56) has provided the anthropologist with a tool of great potential usefulness in the evaluation of populations of mixed origin. In order to use this system to its full advantage, it is necessary to have considerable information on groups whose origin can with considerable certainty be labelled "mongolian" or "nonmongolian." The present study, undertaken as a contribution towards expanding knowledge of the distribution of the Diego system, is concerned with the findings in 75 Asiatic Indians, 108 American Apache Indians, and 775 West African Negroes.

\section{MATERIALS AND METHODS}

Asiatic Indians. All the Indians were students at the University of Michigan at the time of the study. Forty-four came from the state of Bombay, the remaining thirty-one came from other provinces, as indicated on the map (fig. 1). All typing tests were performed within 24-hours of the collection of the blood.

American Apaches. Specimens were obtained from 108 persons requesting outpatient treatment for a wide variety of causes at the United States Public Health Service Indian Hospital at Mescalero, New Mexico, and shipped by air mail to Ann Arbor. Bloods were tested within 4 to 9 days of collection.

The persons bled were presumably all residents of the Mescalero Apache Indian Reservation. The total sample, however, was heterogeneous as to the tribal origins of these persons; that is, on the basis of statements made at the time the blood was drawn there were 47 Mescalero, 23 Chiricahuas, three Mescalero-Chiricahaus, 15 persons the offspring of marriages between Mescaleros and other Indians (among whom the "other Indian" spouses num- bered three Piuma, one Navajo, one $\mathrm{Pu}$ eblo, one Commanche, 6 listed as Mexican, and two unknown), 11 pure blooded Indians of other tribes (two Choctaw, three San Carlos, one Kiowa, two Lipan, and three listed merely as Apache) and 9 persons the offspring of Indian-Caucasian marriages. The entire group will be referred to as Mescalero Reservation Indians.

Negroes. All African bloods were collected as part of a comprehensive survey in which the bloods were examined for sickling, hemoglobin, haptoglobin, and red blood cell antigen types. This report is concerned with only the tests for the $\mathrm{Di}$ ego antigen on these bloods. The complete results of the survey will be presented elsewhere.

Two hundred and sixty-two oxalated specimens were received from the Institute of Hygiene, Abijan, Ivory Coast. A little less than half of the total came from 5 tribes: Mossi, 36; Kru, 36; Guéré, 21; Malinké, 18; and Bété, 12.

The second source from which 513 samples were received was the Institute of the American Foundation for Tropical Medicine, Harbell, Liberia. The numbers of samples from tribes from which more than 20 specimens were received were: Webbo, 66; Kpelle, 65; Kru, 43; Loma, 35; Bassa, 30; Gebo, 27; and Gio, 26. One hundred and thirty-eight samples were unidentified as to tribal affiliation.

All specimens were air shipped to the United States in ice packed thermos containers and were tested within 4 to 7 days after collection.

Serums. The anti-Diego serum used was kindly supplied by Dr. M. Layrisse. All other typing serums were obtained from commercial sources, the methods of test-

\footnotetext{
1 This investigation was supported in part by a grant from the United States Atomic Energy Commission (project AT (11-1)-405).
} 
ing being as described by the vendor of each particular serum. All tests were performed in tubes with washed $2 \%$ red blood cell suspensions, using the antiglobulin method to detect reactions with all nonsaline-agglutinating antibodies.

In order to conserve serum, a two stage screening procedure, in which only those bloods positive for certain reactions were then tested with other reagents, was used as follows :

\begin{tabular}{ll}
$\begin{array}{c}\text { Blood } \\
\text { positive } \\
\text { for }\end{array}$ & \multicolumn{1}{c}{ Then tested for } \\
\hline $\mathrm{A}$ & $\begin{array}{l}\mathrm{A}_{1} \\
\mathrm{C}\end{array}$ \\
$\mathrm{E}$ & $\mathrm{e}(\mathrm{e}$ negatives were retested with \\
$\mathrm{k}$ & $\mathrm{k}$
\end{tabular}

Screening for $\mathrm{D}^{\mathrm{u}}$ was performed by testing all bloods negative to saline anti-D with a potent incomplete anti-D by the antiglobulin method.

\section{RESULTS}

Diego antigen. The frequencies of the Diego antigen among the populations reported are listed in table 1 . The 4 Diegopositive Apache bloods came from three Mescalero and one "Apache" (tribe unknown). Since the two tribes (Mescalero and Chiricahua) did not differ significantly in the frequency of the Diego antigen ( $P=0.28$, by the exact $2 \times 2$ test), the results for these two tribes as well as the three Mescalero-Chiricahuas were pooled to yield a frequency of positive reactors for the Diego antigen of $4.1 \%$.

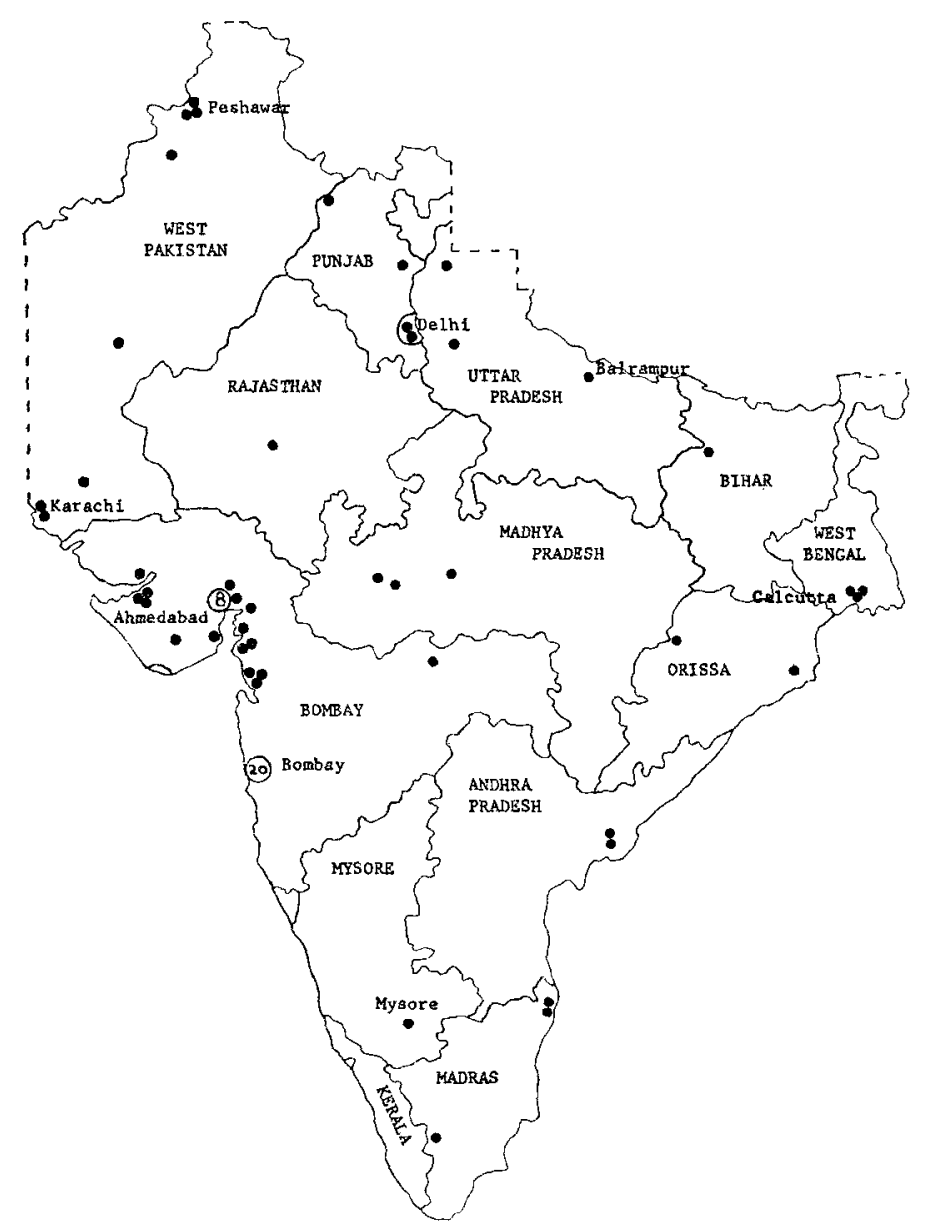

Fig. 1 Birthplaces of 75 Indian students at the University of Michigan. 
One of the African bloods from the Mossi tribe gave a weak Diego reaction which was interpreted as either a false

TABLE 1

Frequency of the Diego antigen

\begin{tabular}{lcc}
\hline & Number & Dia positive \\
\hline Africans & 775 & $0\left(1^{1}\right)$ \\
$\begin{array}{l}\text { Mescalero Reservation } \\
\quad \text { Indians }\end{array}$ & 108 & $4(3.7 \%)$ \\
Apaches $^{2}$ & 73 & $3(4.1 \%)$ \\
Asiatic Indians & 75 & 0
\end{tabular}

1 The Diego character of one blood was not fully resolved-see text.

${ }^{2}$ Includes 47 Mescaleros, 23 Chiricahuas, and three Mescalero-Chiricahuas. The $4 \mathrm{Di}^{\mathrm{a}}$ positive bloods were from three Mescaleros and one "Apache" (no tribe indicated). positive or a true variant, for in an absorption experiment, this blood failed to remove the anti-Diego activity of the serum when tested against a known positive reactor. The possibility remains that this single positive reaction may have indicated a mutation at the $\mathrm{Di}^{\mathrm{a}}$ locus, but because the blood failed to absorb antiDiego completely, it was scored as negative.

Other blood groups. Both to gauge the representativeness of this material and to extend knowledge on the serotypes of man, other blood groupings were also performed. A comparison of the observed blood group frequencies with those published in Mourant's "The Distribution of the Human Blood Groups" ('54) indicated that these two groups (Asiatic and American Indi-

TABLE 2

Blood group frequencies among American Indians from the Mescalero Reservation, New Mexico, and Asiatic Indians

\begin{tabular}{|c|c|c|c|c|}
\hline & $\begin{array}{l}\text { Gujarati } \\
\text { Indians }\end{array}$ & $\begin{array}{c}\text { Total } \\
\text { Asiatic } \\
\text { Indians }\end{array}$ & Apaches: & $\begin{array}{c}\text { Mescalero } \\
\text { Reservation } \\
\text { Indians }\end{array}$ \\
\hline$\overline{A_{1}}$ & .225 & .213 & .466 & .444 \\
\hline$A_{2}$ & .050 & .040 & .014 & .009 \\
\hline B & .350 & .373 & 0 & .019 \\
\hline 0 & .350 & .347 & .521 & .509 \\
\hline \multirow[t]{2}{*}{$A_{1} B$} & .025 & .027 & 0 & .019 \\
\hline & $N=40$ & $\mathbf{N}=75$ & $\mathbf{N}=73$ & $N=108$ \\
\hline $\mathbf{M M}$ & .475 & .467 & 699 & .704 \\
\hline $\mathrm{MN}$ & .325 & .347 & .274 & .278 \\
\hline \multirow[t]{2}{*}{ NN } & .200 & .186 & .027 & .018 \\
\hline & $N=40$ & $N=75$ & $N=73$ & $\mathrm{~N}=\overline{108}$ \\
\hline $\mathbf{P}+$ & $.800 / 40$ & $.787 / 75$ & $.647 / 34$ & $.574 / 61$ \\
\hline $\mathbf{K}+$ & $.025 / 40$ & $.013 / 75$ & $0 / 73$ & $0 / 108$ \\
\hline $\mathrm{Fy}^{\mathrm{a}}+$ & $.775 / 40$ & $.827 / 75$ & $.593 / 54$ & $.690 / 84$ \\
\hline $\operatorname{Le}(a-b+)$ & $.850 / 40$ & $.760 / 75$ & $.742 / 31$ & $.796 / 49$ \\
\hline $\operatorname{Le}(\mathbf{a}+\mathbf{b}-)$ & $.100 / 40$ & $.200 / 75$ & $0 / 31$ & $0 / 49$ \\
\hline $\operatorname{Le}(a-b-)$ & $.050 / 40$ & $.040 / 75$ & $.258 / 31$ & $.204 / 49$ \\
\hline CCDEe & 0 & 0 & .014 & .029 \\
\hline CCDee & .300 & .307 & .225 & .229 \\
\hline $\mathrm{C}^{\mathrm{w}} \mathrm{CDee}$ & 0 & .013 & 0 & 0 \\
\hline CcDee & .300 & .307 & .042 & .048 \\
\hline Ccdee & .050 & .027 & 0 & 0 \\
\hline CCDEE & 0 & 0 & .028 & .019 \\
\hline CcDEe & .075 & .133 & .423 & .429 \\
\hline ccDEE & .025 & .013 & .183 & .162 \\
\hline ccDEe & .075 & .093 & .070 & .076 \\
\hline ccDee & .025 & .013 & .014 & .009 \\
\hline \multirow[t]{2}{*}{ ccdee } & .150 & .093 & 0 & 0 \\
\hline & $N=40$ & $\mathbf{N}=75$ & $N=71$ & $N=\overline{105}$ \\
\hline
\end{tabular}

1 Pooled Mescaleros, Chiricahuas, and Mescalero-Chiricahuas.

2 Among the Mescalero Reservation Indians, 72 of the $79 \mathrm{C}$ positive bloods were tested for $\mathrm{C}^{\mathrm{w}}$ and found negative. 
ans) were acceptable as representative samples. Table 2 presents the findings in the other blood group systems studied.

Of the Asiatic Indians, 40 persons whose parents came from the province of Gujarat to the north of Bombay, were analyzed separately as the closest approximation to a homogeneous group. The majority of the students listing their birthplace as Bombay were Gujaratis so that the Gujarati and Bombay phenotype frequencies will be closely similar. Since information as to caste was not obtained, and it is known that even within the same caste significant differences exist between endogamous groups (Sanghvi and Khanolkar, '50) it was not expected that the sample would be homogeneous; chi squares, however, for the comparison between observed and expected frequencies for the Gujarati, were not significant ( $\mathrm{ABO}, 1.45 ; \mathrm{MN}, 3.52$, for both d.f. $=1$ ).

Blood group frequencies for the Apaches were determined from a sample made by pooling Mescalero, Chiricahua, and Mescalero-Chiricahua Indians. The chi squares obtained by the $2 \times 2$ contingency tables did not indicate between tribe heterogeneity for the $A B O, F y, P$, and $R$ h systems. Chi square for the MN system was significant $(6.2$, d.f. $=1)$. The significance to be attached to this observation is not clear and the data are nevertheless presented in the pooled form. The column headed Mescalero Reservation Indians pre- sents the blood group frequencies for the entire group as representative of the Mescalero Reservation area.

Some caution must be exercised in the interpretation of the Lewis blood types of the Mescalero Reservation Indians in that the actual presence and size of the Le $(a-b-)$ class may be an artifact caused by the age of the samples at testing.

Blood group gene frequencies for the selected groups, as calculated by the methods described by Mourant ('54), are presented in table 3 .

\section{DISCUSSION}

Diego. The findings reported here confirm the reports that the Diego antigen is lacking among Negroes (see Layrisse, '58 for a review); however, this is the first extensive report on Africans. Layrisse and Arends ('57) had examined the blood of 107 Africans distributed among 5 tribes with negative results. Of the 775 Africans tested in the present study, 10 tribes are represented by at least 20 members. Quite possibly, a large proportion of the 138 persons unidentified as to tribal origin also were members of the same 10 tribes, so that each tribe actually is represented by a greater minimum number than that recorded. Be that as it may, the size of the total sample tested here makes it certain that the Diego antigen does not exist among native West Africans with any reasonably detectable frequency.

TABLE 3

Blood group gene frequencies among Apaches of the Mescalero Apache Reservation and Gujarati of India

\begin{tabular}{|c|c|c|c|c|c|}
\hline \multirow{2}{*}{ System } & \multirow{2}{*}{ Gene } & \multirow{2}{*}{ Gujarati } & \multicolumn{3}{|c|}{ Apache } \\
\hline & & & Mescalero & Chiricahua & Total \\
\hline \multirow[t]{4}{*}{$\mathrm{ABO}$} & $\overrightarrow{p_{1}}$ & .153 & .301 & .166 & .269 \\
\hline & $\mathrm{p}_{2}$ & .040 & .014 & 0 & .009 \\
\hline & $q$ & .237 & 0 & 0 & 0 \\
\hline & $\mathbf{r}$ & .571 & .684 & .834 & .731 \\
\hline \multirow[t]{2}{*}{ MN } & $\mathbf{M}$ & .639 & .894 & .740 & .836 \\
\hline & $\mathbf{N}$ & .362 & .106 & .260 & .164 \\
\hline $\begin{array}{l}\mathbf{P} \\
\mathbf{K}\end{array}$ & $\underline{\mathbf{p}}$ & $\begin{array}{l}.447 \\
.987\end{array}$ & .632 & .603 & .594 \\
\hline Fy & Fy & .474 & .675 & .577 & .638 \\
\hline \multirow[t]{6}{*}{$R h$} & $\mathrm{CDE}$ & 0 & .025 & .046 & .015 \\
\hline & $\mathrm{CDe}$ & .443 & .442 & .454 & .471 \\
\hline & $\mathrm{cDE}$ & .100 & .453 & .411 & .450 \\
\hline & $\mathrm{cDe}$ & .029 & .080 & .089 & .064 \\
\hline & Cde & .070 & 0 & 0 & 0 \\
\hline & cde & .359 & 0 & 0 & 0 \\
\hline
\end{tabular}

1 Includes Mescaleros, Chiricahuas, and Mescalero-Chiricahuas. 
Since no positive reactions were found among the 75 Asiatic Indian students, it can be safely assumed that the Diego antigen at most exists with a very low frequency among Indians in the Bombay area.

Among the Mescaleros, the Diego antigen has a frequency of $3 / 47$ or $6.4 \%$. Because the numbers are small, the Chiricahua were pooled with the Mescalero to yield a frequency of $3 / 73$ or $4.1 \%$. None of the 23 Chiricahau were $\mathrm{Di}^{\mathrm{a}}$ positive, but the actual status of the antigen among the members of this tribe cannot be established until a larger sample is secured.

Other blood groups. Since Sanghvi and Khanolkar have shown that heterogenity exists between endogamous groups within the same caste, the blood group frequencies presented here for the Gujarati have only limited significance; they have been tabulated to demonstrate the general agreement with those already on record for Indian populations.

The Mescalero Apaches (including the Mescalero and Chiricahua) conform to the general blood group frequencies of the North-American Indians described by Mourant ('54), i.e., a high frequency of $O$ (.731) and $M(.836)$ a relatively high frequency of $\mathrm{cDE}(.450)$ and the absence of cde. ${ }^{2}$ Unlike the Fort Apache Indians, however, among whom the CDE frequency was reported to be .125 (Kraus and White, '56), the Mescalero Apache CDE frequency is .015 .

TABLE 4

Observed and expected $R h$ zygote frequencies among 71 Mescalero Apaches ${ }^{1}$

\begin{tabular}{lcc} 
& Observed & Expected \\
\hline CCDEE & .000 & .0002 \\
CCDEe & .014 & .014 \\
CCDee & .225 & .222 \\
CcDee & .042 & .060 \\
CCDEe & .423 & .426 \\
CcDEE & .028 & .013 \\
ccDEE & .183 & .203 \\
ccDEe & .070 & .058 \\
ccDee & .014 & .004 \\
& .999 & 1.0002
\end{tabular}

\footnotetext{
1 Including 45 Mescaleros, 23 Chiricahuas, and three Mescalero-Chiricahuas. Chi squares with one degree of freedom are:

Within tribe-Mescalero, 1.63; Chiricahua, 1.21.

Between tribe-Mescalero-Chiricahua, 2.84.

Total for the figures reported in this table, 2.98 .
}

There is good agreement between the observed and expected zygote proportion (table 4). A significant difference between the observed and expected zygote proportions among the Fort Apache Indians was taken as evidence for selection, but the Kraus and White $\mathrm{Rh}$ typings have been criticized on technical grounds (Chown, '57).

\section{SUMMARY}

The Diego antigen was not found among 75 Asiatic Indians or among 775 West African Negroes. The antigen was found, however, on the red blood cells of 4 of 108 Indians from the Mescalero Apache Reservation, New Mexico.

Blood grouping of the Asiatic Indians and Apaches were performed for the ABO, MN, Rh, P, Kell, Duffy, and Lewis. Only limited information can be drawn from the blood groupings of the Asiatic Indians, due to their diverse origins.

The Mescalero-Chiricahua combined gene frequencies were in general similar to those previously reported for American Indians as demonstrated by high frequencies for the genes responsible for the $\mathrm{O}$ (.731) and $\mathrm{M}(.836)$ reactions, relatively high $\mathrm{CDE}$ gene frequency (.450) and absence of the cde gene-complex.

\section{ACKNOWLEDGMENTS}

The anti-Diego serum used in this study was very generously supplied by Dr. M. Layrisse. The Liberian blood samples were drawn under the supervision of Dr. Frank Livingstone, and the Ivory Coast samples under that of Dr. G. Binson. Mr. Peter Kunstadter and Dr. H. E. Sutton cooperated in making the Apache bloods available for this study.

\footnotetext{
2 Brown et al. ('58) have reported gene frequencies which differ slightly from those reported here on the basis of these very data. The discrepancy lies in the facts that two samples were discovered to be repeats, bringing the total from 110 to 108 and that more complete tribe information became available enabling the gene frequency calculations to be made for a reasonably pure Apache group, whereas the gene frequencies reported by Brown et al. were computed for the entire group.
} 


\section{LITERATURE CITED}

Brown, K. S., B. L. Hanna, A. A. Dahlberg and H. H. Strandskov 1958 The distribution of blood group alleles among Indians of Southwest North America. Am. J. Human Genetics, 10: 175 .

Chown, B. 1957 Problems in blood group analysis (Letter to the Editor) Am. Anthropologist, 59: 885

Kraus, B. S., and C. B. White 1956 Microevolution in a human population. A study of social endogamy and blood type distribution among the Western Apache. Ibid., 58: 1017.
Layrisse, M. 1958 Anthropological considerations of the Diego ( $\mathrm{Di}^{\mathrm{a}}$ ) antigen. Am. J. Phys. Anthrop., 16: 173 .

Layrisse, M., and T. Arends 1956 High incidence blood group found in Venezuelan Indians. Science, 123: 633.

1957 The Diego blood factor in Negroid populations. Nature, 181: 118 .

Mourant, A. E. 1954 The Distribution of the Human Blood Groups. Blackwell Scientific Publications, Oxford.

Sanghvi, L. D., and V. R. Khanolkar 1950 Data relating to seven genetical characters in six endogamous groups in Bombay. Ann. Eugenics, 15: 52. 